\title{
Supporting at-Risk University Business Mathematics Students: Shifting the Focus to Pedagogy
}

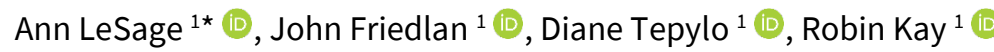

${ }^{1}$ Ontario Tech University, CANADA

`Corresponding Author: ann.lesage@ontariotechu.ca

Citation: LeSage, A., Friedlan, J., Tepylo, D., \& Kay, R. (2021). Supporting at-Risk University Business Mathematics Students: Shifting the Focus to Pedagogy. International Electronic Journal of Mathematics Education, 16(2), em0635. https://doi.org/10.29333/iejme/10893

\begin{tabular}{|c|c|}
\hline ARTICLE INFO & ABSTRACT \\
\hline Received: 1 Dec. 2020 & Colleges and universities are grappling with supporting underprepared students in mathematics. While research \\
\hline Accepted: 17 Jan. 2021 & $\begin{array}{l}\text { examines the demographics of students and the effects of changing the number of preparatory courses, few } \\
\text { studies examine the impact of pedagogical practices on student outcomes. This study investigated the effect of } \\
\text { an alternative pedagogy, the Thinking Classroom framework, on student attitudes and learning performance in a } \\
\text { first-year university business mathematics course. The Thinking Classroom approach focuses on collaborative } \\
\text { problem-solving on vertical non-permanent surfaces (VNPS). Students rated the overall course experience and } \\
\text { collaborative classroom experience highly after participation in the Thinking Classroom. Students in the Thinking } \\
\text { Classroom had a significantly higher average grade point average than students in the control group. }\end{array}$ \\
\hline
\end{tabular}

Keywords: thinking classroom, post-secondary, business mathematics, students at-risk, instructional design

\section{INTRODUCTION}

In many colleges and universities, failure rates in first-year mathematics courses have increased (Cox, 2015; Kajander \& Lovric, 2005; Quarles \& Davis, 2017). In applied disciplines such as business and economics, many students are underprepared and struggling in mathematics (Arnold \& Straten, 2012; Ballard \& Johnson, 2004; Laging \& Voßkamp, 2017). Research exploring the determinants of student success in introductory post-secondary, mathematics-related courses highlight factors such as demographics (Brown-Robertson et al., 2015), motivation (Arnold \& Straten, 2012; Kajander \& Lovric, 2005), and the absence of foundational concepts (Ballard \& Johnson, 2004; Kajander \& Lovric, 2005; Orpwood et al., 2011, 2014; Stienke, 2017). However, limited research exists regarding the relationships among classroom pedagogy, student perceptions, and student learning in postsecondary mathematics courses (Brown-Robertson et al., 2015; Laging \& Voßkamp, 2017; Quarles \& Davis, 2017; Seaton et al., 2014). The purpose of this paper is to extend the existing research by examining an intervention aimed to address the interrelationship between pedagogy, learning and affect.

This study adopted a pedagogical framework called the Thinking Classroom to support students struggling with mathematics. The Thinking Classroom (Liljedhal, 2016) aligns with the flipped-classroom approach, but focuses on in-class pedagogies. These pedagogies are learner-centred (Von Konsky et al., 2014) and focus on active engagement (Haug et al., 2019; Harsh \& Young, 2015) through problem-solving, sense-making, and peer-led collaborations (Cox, 2015; Hooker, 2011; Seaton et al., 2014). The research question addressed in this paper is: How does the Thinking Classroom framework influence student attitudes and learning performance in a first-year business mathematics course?

\section{LITERATURE REVIEW}

The Thinking Classroom framework was adapted for this intervention as it addresses affective factors and knowledge gap issues known to influence learning performance in post-secondary mathematics courses. The literature review examines three interconnected themes: (1) student challenges with mathematics, (2) flipping the classroom as a pedagogy for supporting students, and (3) the Thinking Classroom framework. 


\section{Student Challenges with Mathematics}

Research on students' struggles with mathematics exists at all levels of education, from elementary to post-secondary to teacher education. The research highlights two key elements that influence students' interactions with mathematics: affective factors and knowledge gaps influencing learning performance.

Although affective factors include a range of emotions and attitudes, two affective components that are important for postsecondary students learning mathematics are self-efficacy and anxiety (Arnold \& Straten, 2012; Liljedahl, 2005; Phelps \& Evans, 2006; Woodard, 2004). Self-efficacy is an individual's belief in their capacity to impact their success in a given area (Bandura, 1997). Students with low self-efficacy about mathematics often think they will not succeed no matter their effort, leading to limited engagement with learning activities (Pajares, 1996). Mathematics anxiety is a strong negative reaction to mathematics that is thought to originate from certain teaching strategies (Ashcraft \& Krause, 2007). Like self-efficacy, math anxiety often leads to math avoidance. However, math anxiety also "functions like a resource-demanding secondary task" (Ashcraft \& Krause 2007, p. 1) occupying students' working memory and exacerbating weakness in mathematical knowledge.

In combination with affective factors, mathematical knowledge gaps influence learning performance and student success at the post-secondary level. Identifying and addressing the mathematics knowledge gaps that affect learning performance in first year post-secondary mathematics level is being researched at Canadian and American colleges and universities (Cox, 2015; Kalajdzievska, 2014; Laging \& Voßkamp, 2017; Orpwood \& Brown, 2011, 2014; Quarles \& Davis, 2017). For example, in Canada, from 2006 to 2011, the College Math Project investigated the state of mathematical achievement of first-year students from 24 Ontario community colleges enrolled in business and technology programs (Byers, 2014). The research identified knowledge gaps that interfered with successful participation in college diploma programs, including order of operations, fractions, decimals, percentages, ratio and proportion, and basic algebra (Orpwood et al., 2011, 2014). Related research supports these findings identifying student knowledge gaps in basic algebra (Ballard \& Johnson, 2004) and elementary mathematics concepts including order of operations and rational numbers (Ballard \& Johnson, 2004; Kajander \& Lovric, 2005; Stienke, 2017).

Given the influence of knowledge gaps and affective issues on student success, it is important to consider past efforts to address these issues in post-secondary mathematics. Research shows that offering additional procedural-focused courses does not improve student learning performance (Xu \& Dadger, 2018; Quarles \& Davis, 2017). However, recent studies suggest that changing instructional practice can be an effectual intervention for students in first year mathematics courses (Orpwood et al., 2011). For example, focusing on conceptual understanding (Cox, 2015), peer-tutoring (Hooker, 2011) and interactive class discussions can effectively support student engagement and learning. Additionally, collaborative problem-solving can help relieve post-secondary students' math anxiety in developmental mathematics courses (Cafarella, 2014; Phelps \& Evans, 2006; Woodard, 2004).

Research arguing for changes in pedagogy is also emerging for economics and marketing courses. Brown-Robertson et al. (2015) found virtual tutoring combined with group problem solving and class discussions an effective intervention for underserviced, racially diverse students in economics courses. Rassuli and Manzer (2005) recommended using team-learning pedagogy in an economics course to improve students' attitudes and contribute to the mastery of course material. Students in Haug et al.'s (2019) study appreciated a variety of pedagogical approaches for improving engagement in third and fourth year marketing courses. Haug's students indicated that working in small groups of two-to-three peers to solve complex problems where the problems are relatable and that help connect course content contributed to improved engagement and understanding of course material.

Although research supports incorporating these pedagogies to improve student learning and engagement, such practices require ample class time. As such, how can instructors incorporate these pedagogies and still cover course content? One solution to address limitations in class time is to flip the classroom.

\section{Flipping the Classroom: A Pedagogy for Supporting Students}

Flipping a mathematics classroom typically involves students watching online instructional videos outside of class with class time dedicated to problem-solving (Sarkar et al., 2019). A flipped classroom approach can help students construct meaning (Davis \& Minifie, 2013; Herried \& Schiller, 2013), uncover misconceptions (Butt, 2014; Critz \& Knight, 2013), increase engagement and motivation (Critz \& Knight, 2013; Hoffman, 2014; McGlaughlin et al., 2014), and improve peer and student-teacher interactions (Gaughan, 2014).

Although an emphasis on active and collaborative learning strategies in the classroom is inherent in the flipped classroom approach (Gannod et al., 2008; Toto \& Nguyen, 2009), flipped teaching is typically compared to lecture-based approaches. Limited research, however, has been conducted on what actually occurs in a flipped classroom (Kay et al., 2018). Sarkar et al. (2019) add that flipping the classroom can allow for in-class activities that promote higher-order thinking skills, but the act of flipping the classroom does not guarantee effective in-class activities.

Consequently, in our efforts to revise a first-year business mathematics course, we contemplated how to use existing research to modify the classroom pedagogy to improve student attitudes and achievement. We adopted the Thinking Classroom (Liljedahl, 2016) as the foundational framework for the face-to-face component of the flipped classroom. We reasoned that the Thinking Classroom had the potential to support students struggling with mathematics, including affective and cognitive domains.

\section{The Thinking Classroom Framework}

Students encultured in traditional mathematics classrooms where instructors explain solutions to problems in step-by-step detail often become dependent on the instructors' thinking or the textbook explanations and have difficulty engaging with sense- 
making on their own (Liljedahl, 2016; Yackel \& Rasmussen, 2002). Shifting the responsibility for learning to students is essential to encourage sense-making where students recognize situations and the interconnected nature of mathematical ideas and concepts (Cox, 2015; Yackel \& Rasmussen, 2002). One way to shift to a student-centred learning environment is through the Thinking Classroom framework (Liljedahl, 2016).

The Thinking Classroom approach is grounded in research on: creating mathematically rich learning environments (Mason et al., 2010), creating classroom norms (Yackel \& Rasmussen, 2002), focusing on student engagement through collaborative problemsolving, and assisting students to construct their mathematical knowledge (Grouws \& Cebulla, 2000; Heibert et al., 1997; Hennington \& Stein, 1997; Stein et al., 1996). This approach infuses specific pedagogical strategies shown to improve student performance and understanding, including making connections between mathematical ideas explicit (Cox, 2015), using rich problem-solving tasks that support multiple solution strategies (Hooker, 2011), and encouraging peer-led collaborative learning (Hooker, 2011; Seaton et al., 2014).

Quality mathematical problems are essential for the Thinking Classroom model. High-quality mathematical problems are cognitively demanding, can be solved in multiple ways, and stimulate sense-making and conceptual understanding (Hooker, 2011; Smith et al., 2008). Sense-making requires students to take ownership of the problem-solving process as opposed to mirroring the instructor's preferred solution strategy (Hiebert et al., 1997; Liljedahl, 2016). Students develop a capacity to think and reason, as they make sense of the problem and determine how to solve it in a way that makes sense to them (Stein \& Lane, 1996; Stein et al., 1996). Active problem solving and facilitating insightful experiences can provide students with opportunities to improve their mathematical knowledge and positively influence the affective domain, particularly for anxious mathematics learners (Liljedahl, 2005).

Liljedahl's Thinking Classroom focuses on orchestrating student collaboration and productive discussions by using vertical non-permanent surfaces (VNPS) such as whiteboards, blackboards, or windows. Work on a VNPS in teams increases student focus (Seaton et al., 2014) and improves students' persistence, participation, and enthusiasm (Liljedahl, 2016). VNPS encourage students to experiment, take risks in their learning and modify their written responses (Forrester et al., 2017; Liljedahl, 2016). VNPS also provide opportunities for students to share their solution strategies, giving everyone a voice in class discussions (Seaton et al., 2014; Swan, 2006) and building a stronger sense of classroom community (Forrester et al., 2017; McGregor, 2016). Encouraging collaborative problem-solving can empower students as they realize they are not alone in their struggle with mathematics (Cafarella, 2005; Phelps \& Evans, 2006).

Research on the use of VNPS in post-secondary mathematics courses is long-standing and positive. Studies have found that VNPS encourage active learning in tutorials (Jones, 1989) and improve mathematics problem-solving (Seaton et al., 2014). However, a search of the literature found no research on the use of VNPS or the Thinking Classroom in post-secondary business mathematics courses.

\section{Research Question}

The research question addressed in this paper is: How does the Thinking Classroom framework influence the affective attitudes and learning performance of struggling students enrolled in a first-year business mathematics course?

\section{METHODOLOGY}

\section{Participants}

The participants in this study consisted of 124 undergraduate students enrolled in a four-month, first-year business mathematics course. These students were divided into two groups. The control group of 62 students who did not experience the Thinking Classroom from January to April 2018. The treatment group of 62 students experienced the Thinking Classroom model of teaching from January to April 2019.

\section{Research Design and Data Collection}

To assess student perceptions of the Thinking Classroom model, we used an anonymous survey consisting of six 5-point Likert and three open-response questions. The Likert questions focused on student ratings of the value of collaborative problem-solving and overall course experience. The open-ended questions asked students to comment on what they found most useful about learning in the Thinking Classroom and to provide suggestions for improvements. At the end of the course, 54 out of 62 students (87\%) completed the survey, and 26 students (42\%) provided written comments.

To assess learning performance, we used a quasi-experimental research design (Creswell \& Creswell, 2018) comparing learning performance (final grades) between the control group (non-Thinking Classroom model) and the treatment group (Thinking Classroom model). While we could not randomly assign students to groups, the control group provides a reasonable comparison to the treatment group, because each course implemented the same curriculum and used comparable midterm and final examination assessments. Additionally, the student populations for both groups were similar. The two groups included approximately the same proportion of students who had previously failed the course: control group, $n=25(40 \%)$ versus the treatment group, $n=30$ (48\%).

\section{Context}

In the Bachelor of Commerce (BCom) program, the introductory business mathematics course creates a significant bottleneck for progress through the program. Although this course addresses concepts explored in middle and secondary school 
Table 1. Survey Results of Students' Perceptions of the Thinking Classroom $(n=54)$

\begin{tabular}{|c|c|c|c|c|}
\hline & Mean (SD) & \% Disagree ${ }^{1}$ & $\%$ Neutral & $\%$ Agree $^{2}$ \\
\hline Overall Course Experience & $4.5(0.7)$ & $0 \%$ & $9 \%$ & $91 \%$ \\
\hline Collaborative Problem Solving was Helpful & $4.6(0.6)$ & $0 \%$ & $6 \%$ & $94 \%$ \\
\hline
\end{tabular}

${ }^{1}$ Combination of Strongly Disagree and Disagree responses

${ }^{2}$ Combination of Strongly Agree and Agree responses

mathematics, these concepts present substantial challenges for many first-year university students. Past efforts to address this bottleneck included using different delivery modes (face-to-face, blended, and fully online) and adjusting class size. These variations had a limited effect on student success. Consequently, in 2018 the Faculty of Business and Information Technology (FBIT) collaborated with the Faculty of Education (FED) to implement pedagogical changes to improve student learning and success in the course. Two teacher educators from FED with expertise in mathematics pedagogy, both of whom are authors on this paper, were approached by FBIT to redesign the business mathematics course within the existing hybrid structure (1.5 hours online +1.5 hours face-to-face classes +1.5 hours face-to-face tutorials). The two FED instructors developed a Thinking Classroom model for the course and taught all classes and tutorials in the treatment group from January to April 2019. The online component in the course incorporated best practices in video design (Kay, 2014; Kay \& Kletskin, 2012; LeSage et al., 2019) focusing on direct instruction, while the Thinking Classroom model (Liljedahl, 2016) was the foundational framework for the face-to-face components of the course. The FED instructors collaborated with FBIT instructors to design the mid-term and final course assessments.

\section{Procedure}

To incorporate the Thinking Classroom model for face-to-face sessions (classes and tutorials), the instructors used rich problem-solving tasks. We sequenced the tasks with consideration given to the complexity of the mathematical concepts explored. During face-to-face sessions, students worked collaboratively to solve problems in ways that made sense to them. The instructors did not explicitly model solution strategies. Instead, students were encouraged to collaborate with members of their group using vertical whiteboards (VNPS) or to speak with other students in the classroom. When most groups had arrived at a solution, they shared their solution strategies with the class or with the instructor. This collaborative approach and classroom discourse often led to multiple solution strategies for a problem.

During class discussions, the instructors often asked questions that encouraged students to make connections between business and mathematical concepts. For example, we encouraged students to compare strategies for calculating stepped commission with strategies for calculating income tax - they are different business contexts but address the same mathematical concept. As the course progressed, the instructors asked questions to encourage student movement from strictly numerical to more sophisticated algebraic solutions.

By using vertical whiteboards (VNPS) for collaborative problem-solving, the students' strategies were visible throughout the room. As such, the instructors could quickly identify groups requiring additional support. Working with individual groups, the instructors asked probing questions to encourage student progress without removing the element of productive struggle. The VNPS also allowed instructors to quickly view student strategies and plan for effective whole class consolidation.

\section{RESULTS}

\section{Student Perceptions of the Thinking Classroom}

Student feedback on their experiences in the Thinking Classroom was positive. As depicted in Table 1, over $90 \%$ of the students agreed or strongly agreed that their overall experiences in the course helped them learn and $94 \%$ of students agreed or strongly agreed that collaborative problem-solving, in particular, was helpful to their learning.

Support for the Thinking Classroom model was echoed in students' responses to the open-ended survey questions. Of the 52 responses, 44 were positive and focused on the Thinking Classroom pedagogy, including the value of collaborative learning. The high rating for the helpfulness of collaborative problem-solving was supported by student responses to the open-ended survey questions, including:

The things that I've found most helpful while learning in this course is that the teachers got us to work together in small groups and hear different thought processes. It helped us answer our own questions and clearly see what mistakes were being made.

The best way of learning is with a team, and I find that most effective.

No boring lectures only. In class problems made kids move around, work and learn.

I took Business Math 1 last semester and comparing the two semesters with this course, I personally believe this semester was taught way better.

In addition to the responses indicating that collaborative problem-solving supported student learning, many other comments highlighted students' affective reactions to the Thinking Classroom pedagogy, including: 
Table 2. Comparing Student Perceptions based on Initial Worries: Mean Rating $(n=40)$

\begin{tabular}{|c|c|c|c|}
\hline & Worried $(n=23)$ & Non-worried $(n=17)$ & Mann Whitney $(d f=2)$ \\
\hline \multirow{2}{*}{ Overall Course Experience } & \multirow{2}{*}{$4.52(0.7)$} & \multirow{2}{*}{$4.29(0.7)$} & $Z=1.225$ \\
\hline & & & $p=0.220$ \\
\hline \multirow{2}{*}{ Collaborative Problem Solving was Helpful } & \multirow{2}{*}{$4.70(0.5)$} & \multirow{2}{*}{$4.29(0.8)$} & $Z=1.722$ \\
\hline & & & $P=0.085$ \\
\hline
\end{tabular}

Table 3. Comparison of Performance in the Thinking Classroom and Control Groups

\begin{tabular}{|c|c|c|c|c|}
\hline \multirow[b]{2}{*}{ Final Grade } & \multicolumn{2}{|c|}{$\begin{array}{c}\text { Winter } 2019 \\
\text { Thinking Classroom } \\
(n=62)\end{array}$} & \multicolumn{2}{|c|}{$\begin{array}{c}\text { Winter } 2018 \\
\text { Control } \\
(n=62)\end{array}$} \\
\hline & Number of students & Percentage of students & Number of students & Percentage of students \\
\hline$A+$ & 5 & $8 \%$ & 5 & $8 \%$ \\
\hline A & 4 & $6 \%$ & 2 & $3 \%$ \\
\hline A- & 14 & $23 \%$ & 3 & $5 \%$ \\
\hline $\mathrm{B}+$ & 12 & $19 \%$ & 5 & $8 \%$ \\
\hline$B$ & 5 & $8 \%$ & 6 & $10 \%$ \\
\hline B- & 2 & $3 \%$ & 4 & $6 \%$ \\
\hline $\mathrm{C}+$ & 4 & $6 \%$ & 4 & $6 \%$ \\
\hline C & 7 & $11 \%$ & 5 & $8 \%$ \\
\hline $\mathrm{D}$ & 4 & $6 \%$ & 14 & $23 \%$ \\
\hline $\mathrm{F}$ & 5 & $8 \%$ & 14 & $23 \%$ \\
\hline Mean GPA (S.D.) & \multicolumn{2}{|c|}{$2.84(1.21)$} & \multicolumn{2}{|c|}{$1.91(1.46)$} \\
\hline Mean \% (S.D.) & \multicolumn{2}{|c|}{$72 \%(18.1 \%)$} & \multicolumn{2}{|c|}{$63 \%(19.2 \%)$} \\
\hline Median $\%$ & \multicolumn{2}{|c|}{$77 \%$} & \multicolumn{2}{|c|}{$64 \%$} \\
\hline
\end{tabular}

Null hypothesis: median Winter $2019=$ median Winter 2018

Mann-Whitney U test: $Z$-score $=3.538$; $p$-value $=0.0004$

I loved the in-class learning where we do work and word problems.

I love $[\ldots]$ the collaborative aspect to the learning with the white boards.

The class was cooperative which makes it comfortable for us to learn.

I enjoyed learning new concepts.

\section{Students' confidence levels}

Given that the primary purpose of this intervention was to support students struggling with mathematics, we were interested in knowing if students of differing confidence levels perceived the Thinking Classroom intervention differently. Because the survey was anonymous, we used student responses to the Likert-scale survey question, "I was initially worried about success in this course" as a proxy for identifying struggling students. Students were classified as worried if they agreed or strongly agreed with the statement; students were classified as non-worried if they disagreed or strongly disagreed with the statement. The 14 students who responded as neutral to the statement were not included in the analysis. Table 2 compares mean ratings for overall course experience and the helpfulness of collaborative problem-solving between students who self-reported as worried versus not worried about their success in the course.

Worried students had higher mean ratings for overall course experience and collaborative problem solving than the nonworried students did, although the differences were not significant.

\section{Learning Performance}

A comparison of final course grades between the Thinking Classroom group and control group of the business mathematics courses appear in Table 3. Table 3 shows that the Thinking Classroom group had a significantly higher median grade point average than the control group and fewer failures.

Given the historically high failure rates for the business mathematics course, we analysed learning performance of students who had already been unsuccessful in the course. The control group had 25 repeating students $(F=24 ; D=1)$ and the Thinking Classroom group had 30 repeating students $(F=28, D=2)$. For this test, we examined letter grades because the numeric final course grades were not available. Table 4 shows that Thinking Classroom students who were repeating the course had a significantly higher-grade point average, fewer students with Fs and Ds, and more students with As and Bs than the control group students. 
Table 4. Comparison of Performance of Repeating Students in the Thinking Classroom and Control Groups

\begin{tabular}{|c|c|c|c|c|}
\hline \multirow[b]{2}{*}{ Final Grade } & \multicolumn{2}{|c|}{$\begin{array}{c}\text { Repeated in Winter } 2019 \\
\text { Thinking Classroom }(n=30)\end{array}$} & \multicolumn{2}{|c|}{$\begin{array}{c}\text { Repeated in Winter } 2018 \\
\text { Control }(n=25)\end{array}$} \\
\hline & Number of students & Percentage of students & Number of students & Percentage of students \\
\hline$A+$ & 0 & $0 \%$ & 0 & $0 \%$ \\
\hline $\mathrm{A}$ & 0 & $0 \%$ & 0 & $0 \%$ \\
\hline A- & 6 & $20 \%$ & 0 & $0 \%$ \\
\hline $\mathrm{B}+$ & 6 & $20 \%$ & 1 & $4 \%$ \\
\hline $\mathrm{B}$ & 4 & $13.3 \%$ & 3 & $12 \%$ \\
\hline B- & 1 & $3.3 \%$ & 1 & $4 \%$ \\
\hline $\mathrm{C}+$ & 3 & $10 \%$ & 3 & $12 \%$ \\
\hline C & 4 & $13.3 \%$ & 2 & $8 \%$ \\
\hline $\mathrm{D}$ & 3 & $10 \%$ & 9 & $36 \%$ \\
\hline $\mathrm{F}$ & 3 & $10 \%$ & 6 & $24 \%$ \\
\hline Mean GPA (S.D.) & \multicolumn{2}{|c|}{$2.49(1.18)$} & \multicolumn{2}{|c|}{$1.40(1.11)$} \\
\hline
\end{tabular}

Null hypothesis: median Winter $2019=$ median Winter 2018

Mann-Whitney U test: $Z$-score $=3.245 ;$-value $=0.0012$

\section{DISCUSSION}

The intervention described in this paper represents the initial phase of an inter-faculty research project focused on supporting at-risk university mathematics students. The results extend previous research and indicate that the Thinking Classroom model is an effective pedagogical intervention (Liljedahl, 2005, 2016) in a university business mathematics course. Students in the Thinking Classroom section were significantly more successful than students in comparable sections of the course that did not use the Thinking Classroom model.

The learning performance of students in the Thinking Classroom outperformed those in the control group. In the control group $46 \%$ of the students received Ds and Fs while only $14 \%$ of students in the Thinking Classroom received these grades and there were proportionally many more students in the A and B categories. The improved learning performance of the entire Thinking Classroom group is also observed in students who repeated the course, students who were of particular interest in the study. The analysis indicates that repeating students were more successful with the Thinking Classroom pedagogy. Repeating students in the Thinking Classroom section achieved more A and B final grades and fewer final grades of D and F than students in the control group. This finding is important, as one goal of this study was to examine the effectiveness of the Thinking Classroom pedagogy for struggling students. The Thinking Classroom approach was effective for all students in the first-year business mathematics course, including the struggling students. Given the existing research on the knowledge gaps that affect learning performance in first year postsecondary mathematics (Cox, 2015; Kalajdzievska, 2014; Laging \& Voßkamp, 2017; Quarles \& Davis, 2017), the Thinking Classroom pedagogy may be an effective strategy for narrowing these knowledge gaps and supporting students' future success in mathematics.

Because the end-of-course survey was anonymous, we could not analyse the relationship between learning performance and affect (i.e., self-efficacy, math anxiety). However, by combining the survey data with informal student feedback we are able to comment on the influences of the Thinking Classroom on students' self-efficacy (Bandura, 1997; Pajares, 1996) and math anxiety (Ashcraft \& Krause, 2007). The survey data indicates that worried students had mean ratings for overall course experience in the Thinking Classroom model that were statistically the same as the non-worried students. One might expect that worried / math anxious students would have a less satisfactory experience than the less worried students would, but this was not the case. In addition, students regularly voiced their positive reactions to the Thinking Classroom pedagogy. Words like love, enjoy, and comfort, which are not generally associated with learning mathematics, were heard regularly throughout the semester and appeared repeatedly in students' responses to the open-ended survey questions. These findings indicate that the Thinking Classroom approach is effective in supporting math anxious students who have lower self-efficacy beliefs, and may be viable pedagogy to shift students' beliefs about their capacity to learn mathematics.

Our research identifies positive outcomes of the Thinking Classroom on students' learning performance and affective factors (self-efficacy, math anxiety). But, what Thinking Classroom pedagogies did students identify as contributing most to their learning and engagement? Similar to previous research, the students most appreciated collaborative problem-solving (Forrester et al., 2017; McGregor, 2016; Seaton et al., 2014; Wiliam \& Leahy, 2015), interactive class discussions (Haug et al., 2019; Rassuli \& Manzer, 2005) and using VNPS (Jones, 1989; Seaton et al., 2014). The post-course survey showed that worried students rated the helpfulness of collaborative problem solving highly, demonstrating the importance of this aspect of the Thinking Classroom in reducing students' anxieties and increasing their confidence and efficacy as mathematics learners. This finding aligns with previous research asserting that collaborative problem-solving can help relieve post-secondary students' math anxiety (Cafarella, 2014; Phelps \& Evans, 2006; Woodard, 2004). Having students work on VNPS to collaborate and discuss their ideas allowed the students to experience mathematics differently. This strategy provided opportunities for students to see their peers grappling with mathematics and business concepts, and share their solution strategies. In this, the students build their collective knowledge, decrease individual stress / math anxiety and begin to develop their mathematics self-efficacy (Arnold \& Straten, 2012; Bandura, 1997; Cafarella, 2014; Liljedahl, 2005; Phelps \& Evans, 2006). 


\section{Limitations}

Overall, the results from this study suggested that the teaching strategies used in the Thinking Classroom cohort of the firstyear business mathematics course were effective. However, our analysis does not control for confounding factors such as the impact of the instructors or different grading or assessment approaches. Although the design of this study did not allow us to identify the relative contributions of each component of the Thinking Classroom model, the modifications to the instructional design appeared to positively affect the overall academic performance and student success rates in the course.

Encouraging struggling students to actively engage in collaborative problem-solving involves more than having students work together in groups. It involves choosing or developing questions that allow sense-making (Hooker, 2011; Smith et al., 2008) and responding to students with questions that value their solution strategies while pushing them to improve their thinking (Mason et al., 2010). As mathematics teacher educators, we possess the pedagogical knowledge, experience, and expertise to design instruction to encourage active student engagement. This knowledge and skills may not readily transfer to faculty in other disciplines (Goos \& Bennison, 2018). Indeed, we found that collaboration between mathematics education and business faculty required a great deal of negotiation.

\section{CONCLUSIONS AND FUTURE DIRECTIONS}

Further research is needed to explore how the Thinking Classroom model can be extended to post-secondary instructors with limited expertise in mathematics pedagogy. Future research should also use controls to determine the relative impact of various components of the Thinking Classroom model in post-secondary business mathematics. Despite these cautions, the improved student success in this Thinking Classroom, as well as strong student support for the approach indicates this model can be effective and should be explored more broadly in a variety of post-secondary contexts.

Middleton and Spanias (1999) found that when teaching practices that engage and motivate students are used, over time students "learn to enjoy and value mathematics" (p. 82). Our findings support this assertion. We provide evidence of improved achievement and motivation for students enrolled in a first-year business mathematics course that used a student-centred learning approach through creating a Thinking Classroom. This pedagogical intervention shifted responsibility for learning to the students and encouraged collaborative sense-making where students began to understand the interconnected nature of mathematical ideas and concepts.

Author contributions: All authors have sufficiently contributed to the study, and agreed with the results and conclusions.

Funding: No funding source is reported for this study.

Declaration of interest: No conflict of interest is declared by authors.

\section{REFERENCES}

Arnold, I. J., \& Straten, J. T. (2012). Motivation and math skills as determinants of first-year performance in Economics. The Journal of Economics Education, 43(1), 33-47. https://doi.org/10.1080/00220485.2012.636709

Ashcraft, M. H., \& Krause, J. A. (2007). Working memory, math performance, and math anxiety. Psychonomic Bulletin \& Review, 14, 243-248. https://doi.org/10.3758/BF03194059

Ballard, C., \& Johnson, M. F. (2004). Basic math skills and performance in an introductory economics class. Journal of Economic Education, 35, 3-23. https://doi.org/10.3200/JECE.35.1.3-23

Brown-Robertson, L., Ntembe, A., \& Tawah, R. (2015). Evaluating the "underserved student" success in economic principles courses. Journal of Economics and Economic Education Research, 16(3), 13-23.

Butt, A. (2014). Student views on the use of a flipped classroom approach: Evidence from Australia. Business Education \& Accreditation, 6(1), 33-44. http://www.theibfr.com/ARCHIVE/BEA-V6N1-2014-revised.pdf

Byers, P. (2014). Bridging the Mathematics Gap through Learning Outcomes. Final Report for the Ontario Ministry of Training, Colleges and Universities. Seneca College of Applied Arts and Technology.

Cafarella, B. (2014). Exploring best practices in developmental math. Research and Teaching in Developmental Education, 30(2), 35-64.

Cox, R. (2015). You've got to learn the rules: A classroom-level look at low pass rates in developmental math. Community College Review, 43(3), 264-286. https://doi.org/10.1177/0091552115576566

Creswell, J. W., \& Creswell, J. D. (2018). Research design: qualitative, quantitative, and mixed methods approaches (5th Ed.). SAGE.

Critz, C. M., \& Knight, D. (2013). Using the flipped classroom in graduate nursing education. Nurse Educator, 38(5), $210-213$. https://doi.org/10.1097/NNE.0b013e3182a0e56a

Davis, K., \& Minifie, J. R. (2013). Ensuring Gen Y students come prepared for class; then leveraging active learning techniques to most effectively engage them. American Journal of Business and Management, 2(1), 13-19. https://doi.org/10.11634/216796061302228

Forrester, T., Sandison, C., \& Denny, S. (2017). Vertical whiteboarding: Riding the wave of student activity in a mathematics classroom. Australian Mathematics Teacher, 73(4), 3-8. 
Gannod, G. C., Burge, J. E., \& Helmick, M. T. (2008, May). Using the inverted classroom to teach software engineering. In Proceedings of the 30th International Conference on Software Engineering (pp. 777-786). ACM. https://doi.org/10.1145/1368088.1368198

Gaughan, J. E. (2014). The flipped classroom in world history. History Teacher, 47(2), $221-244$. http://www.societyforhistoryeducation.org/pdfs/F14_Gaughan.pdf

Grouws, D. A, \& Cebulla, K. J. (2000). Improving student achievement in mathematics. International Academy of Education and the International Bureau of Education.

Harsh, S., \& Young, J. (2015). Using varied learning environments for deeper learning and student mastery of complex content. The Delta Kappa Gamma Bulletin, Spring, 7-16.

Haug, J. C., Berns Wright, L., \& Huckabee, W. A. (2019). Undergraduate business students' perceptions about engagement. Journal of Education for Business, 94(2), 81-91. https://doi.org/10.1080/08832323.2018.1504738

Henningsen, M., \& Stein, M. K. (1997). Mathematical tasks and student cognition: Classroom factors that support and inhibit highlevel mathematical thinking and reasoning. Journal for Research in Mathematics Education, 29(5), 524-549. https://doi.org/10.2307/749690

Hiebert, J. Carpenter, T., Fennema, E., Fuson, K., Wearne, D., Murray, H., Olivier, A., \& Human, P. (1997). Making sense: Teaching and learning mathematics with understanding. Portsmouth, $\mathrm{NH}$ : Heinemann.

Hooker, D. (2011). Small peer-led collaborative learning groups in developmental math classes at a tribal community college. Multicultural Perspectives, 13(4), 220-226. https://doi.org/10.1080/15210960.2011.616841

Kajander, A., \& Lovric, M. (2005). Transition from secondary to tertiary mathematics: McMaster University experience. International Journal of Mathematical Education in Science and Technology, 36(2-3), 149-160. https://doi.org/10.1080/00207340412317040

Kalajdzievska, D. (2014). Taking math students from "blah" to aha": What can we do? PRIMUS, $24(5), 375-391$. https://doi.org/10.1080/10511970.2014.893937

Kay, R. H. (2014) Developing a framework to create effective problem-based video podcasts. International Journal of Emerging Technologies, 9(1), 22-30. https://doi.org/10.3991/ijet.v9i1.3335

Kay, R. H., \& Kletskin, I. (2012) Evaluating the use of problem-based video podcasts to teach mathematics in higher education. Computers and Education, 59(2), 619-627. https://doi.org/10.1016/j.compedu.2012.03.007

Kay, R., MacDonald, T., \& DiGiuseppe, M. (2018). A comparison of lecture-based, active, and flipped classroom teaching approaches in higher education. Journal of Computing in Higher Education, 31(3), 449-471. https://doi.org/10.1007/s12528-018-9197-x

Laging, A., \& Voßkamp, R. (2017). Determinants of maths performance of first-year business administration and economics students. International Journal for Research in Undergraduate Mathematics Education, 3(1), $108-142$. https://doi.org/10.1007/s40753-016-0048-8

LeSage, A., Kay, R., Tepylo, D. \& Allen, R. (2019). Designing video podcasts to support at-risk university mathematics students. 12th Annual International Conference of Education, Research and Innovation (iCERi). Seville, Spain. https://doi.org/10.21125/iceri.2019.1315

Liljedahl, P. (2016). Building thinking classrooms: Conditions for problem-solving. In P. Felmer, E. Patricio, \& J. Kilpatrick (Eds.), Posing and solving mathematical problems (pp. 361-386). Springer. https://doi.org/10.1007/978-3-319-28023-3_21

Liljedahl, P. G. (2005). Mathematical discovery and affect: The effect of AHA! experiences on undergraduate mathematics students. International Journal of Mathematical Education in Science and Technology, 36(2-3), $219-234$. https://doi.org/10.1080/00207390412331316997

Mason, J., Burton, L., \& Stacey, K. (2010). Thinking mathematically (2nd Ed). Pearson Education Ltd.

Orpwood, G., Schollen, L., Leek, G., Marinelli-Henriques, P., \& Assiri, H. (2011). College Math Project 2010: Final Report for the Ontario Ministry of Education and Ontario Ministry of Training, Colleges and Universities. Seneca College of Applied Arts \& Technology.

Orpwood, G., Schollen, L., Leek, G., Marinelli-Henriques, P., \& Assiri, H. (2014). College Student Achievement Project: Final Report 2014 for Ontario Ministry of Education and Ontario Ministry of Training, Colleges and Universities. Seneca College of Applied Arts \& Technology.

Pajares, F. (1996). Self-efficacy beliefs in academic settings. Review of Educational Research, 66(4), 543-578. https://doi.org/10.3102/00346543066004543

Phelps, J. M., \& Evans, R. (2006). Supplemental instruction in developmental mathematics. The Community College Enterprise, 12(1), 21-37.

Quarles, C. L., \& Davis, M. (2017). Is learning in developmental math associated with community college outcomes? Community College Review, 45(1), 33-51. https://doi.org/10.1177/0091552116673711

Rassuli, A., \& Manzer, J. P. (2005). "Teach Us to Learn": Multivariate analysis of perception of success in team learning. Journal of Education for Business, 81(1), 21-27. https://doi.org/10.3200/JOEB.81.1.21-28

Sarkar, N., Ford, W., \& Manzo, C. (2020). To flip or not to flip: What the evidence suggests. Journal of Education for Business, 95(2), 81-87. https://doi.org/10.1080/08832323.2019.1606771

Seaton, K. A., King, D. M., \& Sandison, C. E. (2014). Flipping the maths tutorial: A tale of n departments. Australian Mathematical Society Gazette, 41(2), 99-113. 
Smith, M. S., Bill, V., \& Hughes, E. K. (2008). Thinking through a lesson: Successfully implementing high-level tasks. Mathematics Teaching in the Middle School, 14(3), 132-138. https://doi.org/10.5951/MTMS.14.3.0132

Stein, M. K., \& Lane, S. (1996). Instructional tasks and the development of student capacity to think and reason: An analysis of the relationship between teaching and learning in a reform mathematics project. Educational Research and Evaluation, 2(1), 5080. https://doi.org/10.1080/1380361960020103

Stein, M. K., Grover, B. W., \& Henningsen, M. (1996). Building student capacity for mathematical thinking and reasoning: An analysis of mathematical tasks used in reform classrooms. American Educational Research Journal, 33(2), 455-488. https://doi.org/10.3102/00028312033002455

Stienke, D. (2017). Evaluating number dense in community college developmental math students. Journal of Research \& Practice for Adult Literacy, Secondary and Basic Education, 6(1), 5-19.

Toto, R., \& Nguyen, H. (2009, October). Flipping the work design in an industrial engineering course. In Frontiers in Education Conference, 2009. FIE’09. 39th IEEE (p.1-4). IEEE. https://doi.org/10.1109/FIE.2009.5350529

Von Konsky, B. R., Martin, R., Bolt, S., Broadley, T., \& Ostashewski, N. (2014). Transforming higher education and student engagement through collaborative review to inform educational design. Australasian Journal of Educational Technology, 30(6), 619-633. https://doi.org/10.14742/ajet.742

Woodard, T. (2004). The effects of math anxiety on post-secondary developmental students as related to achievement, gender, and age. Inquiry, 9(1), 1-5. https://files.eric.ed.gov/fulltext/EJ876845.pdf

Xu, D., \& Dadger, M. (2018). How effective are community college remedial math courses for students with the lowest math skills? Community College Review, 46(1), 62-81. https://doi.org/10.1177/0091552117743789

Yackel, E., \& Rasmussen, C. (2002). Beliefs and Norms in the Mathematics Classroom. In G. Leder, E. Pehkonen, \& G. Törner (Eds.), Beliefs: A Hidden Variable in Mathematics Education? (pp. 313-330). Kluwer Academic Publishing. https://doi.org/10.1007/0306-47958-3_18 